\title{
H2AC18 wt Allele
}

National Cancer Institute

\section{Source}

National Cancer Institute. H2AC18 wt Allele. NCI Thesaurus. Code C162963.

Human $\mathrm{H} 2 \mathrm{AC} 18$ wild-type allele is located in the vicinity of $1 \mathrm{q} 21.2$ and is approximately 1 $\mathrm{kb}$ in length. This allele, which encodes histone H2A type 2-A protein, plays a role in DNA wrapping and compaction. 